\title{
Reconstruction of historical series of life tables and of age-sex structures for the Austrian population in the 19th and the first half of the 20th century
}

\author{
Dalkhat Ediev and Richard Gisser*
}

\begin{abstract}
The paper presents the method and results of reconstructing the Austrian life tables and population age-sex composition for single years in 1870-1940. It also proposes estimates of life tables for the years 1819-1869. The time period covered by the paper is marked by improvements in life expectancy, unstable births dynamics, distortions due to war, territorial changes and migration. For the years since 1870 a multistage reconstructing technique is used which enables to make use of both reference life tables and census populations and also of vital statistics available for the years between censuses. First, life tables are interpolated and used to obtain population projections without migration. Then, net migration between censuses is roughly approximated and - together with deaths statisticsused to improve estimates for life tables. Finally, the estimates for net migration and population age-sex composition between censuses are also improved. Estimates for life tables in 1819-1869 are based on regression models developed from the estimates for the period 1870-1910.
\end{abstract}

\section{Introduction: initial data and data improvements}

Historical mortality and population data for Austria are relatively rich. Life tables are available for years adjacent to the census years starting from the late 1860s (Österreichisches Statistisches Zentralamt 1960, 1967; Findl 1979; Statistik Austria 2005; HLD 2005). First modern census was carried out in 1869, and life

* Dalkhat Ediev (author for correspondence), Vienna Institute of Demography, Austrian Academy of Sciences, Wohllebengasse 12-14, 1040 Vienna, Austria, email: dalkhat.ediev@oeaw.ac.at

Richard Gisser, Vienna Institute of Demography, Austrian Academy of Sciences, Wohllebengasse 12-14, 1040 Vienna, Austria. 
tables based on population data from this census were calculated for 1865/75 already in 1880s (Zeitschrift des Königlich Preussischen Statistischen Bureaus 1881, Österreichisches Statistisches Zentralamt 1967). These and other life tables calculated in the time of Austria-Hungary, however, refer to the population of the Austrian part of the monarchy, the Cisleithania, which was about four times the present-day Austria.

Nonetheless, life tables for the years before 1912 were estimated by Findl (1979) for the so-called Austrian Alpenländer, which covers most of present-day Austria and also some adjacent territories (mainly parts of north-eastern Italy and Slovenia). This geographic entity may well be considered as a good approximation of present-day Austria.

Data on population age-sex structure and data on births consistent with the current geographical area of Austria are available for the time since 1871 . Additionally, data on deaths by single years of age are available for the Austrian Alpenländer for almost all years since the mid-19th century, with some details on deaths distribution by birth cohorts available since the 1880s (Database on Historical Demography of Austria of the Vienna Institute of Demography). For 1830-1850 deaths are available for the Austrian Alpenländer by rough age grouping ( 0 to 1,1 to 4,4 to 20,20 to $40,40-60,60$ to 80,80 to 100 , and $100+$ ) but without distinction of sexes (VID Database). Finally, for the years after 1819 crude numbers of deaths, infant deaths, and also total population and births by sex are available for the Austrian Alpenländer (VID Database).

The available data have been used in different ways in order to shed light on historical dynamics of mortality of the Austrian population. As mentioned above, Findl (1979) developed life tables for the Austrian Alpenländer for the periods adjacent to census years in 1868-1912 based on census and vital statistics. Aggregating data for the Austrian Alpenländer, Gisser (1979) studied trends in population, births, deaths and net migration for 1819-1913. He also presented aggregate mortality indicators and indicated the trend of Austrian life expectancy in 1819-1913 using the stationary population model. However, the rich data resources available were not yet used to derive continuous time series of life tables and of age-sex structures for the Austrian population consistent with the current territory of Austria.

We elaborate on this task and present estimation results for single years 18191940. For the period covered by modern censuses, i.e., starting from the census of 1869, we develop an interpolation technique, which makes use of both the life tables available for periods adjacent to census years and also of vital statistics available for years between the censuses. As was shown elsewhere (Gisser 1979) and as is also suggested by our findings, mortality in Austria was stagnating before the 1870s. Hence, our interpolations cover an important period of life expectancy improvements in Austria. For the preceding years (1819-1869) we develop estimates based on regressions for age-specific death rates, which we derived from our own estimates for the period 1870-1910. 
In the following, we describe the available data as well as improvements applied to the initial data in a systematic way.

\subsection{Population}

We use census data on the Austrian population by sex and single years of age consistent with the current territory available from Statistics Austria (Statistik Austria 2005, Table 8.04) for census dates 31.12.1869, 31.12.1880, 31.12.1890, 31.12.1900, 31.12.1910, 07.03.1923, 22.03.1934 and 17.05.1939. Indeed, some dramatic changes in the territory of Austria happened in the wake of the dissolution of the Habsburg Empire and the reshaping of its parts in 1918. However, the aforementioned estimates of the population performed by Landstätter (1979) are of good quality, as they were aggregated directly from the census data by local areas, i.e., they do correspond to the present-day territory of the country. Landstätter has addressed problems related to age heaping in the original data, although this phenomenon was relatively minor in Austrian census data as the age of respondents was calculated from their date of birth (except in the 1869 census, where it was calculated from the birth year).

Census population age structures were usually available until the age of 95 only (for 1923 only until the age of 80). Therefore, we approximated the population age structure at ages up to 100 using the life table proportions. In the reconstruction procedure, we used projections from one census year to another, i.e., for time intervals longer than five years. Therefore reconstruction biases in census populations in upper age groups may only moderately affect our estimates.

For some periods more thorough manipulations had to be done to census data. Unlike earlier censuses, those conducted in 1923 and later referred to a date other than Dec 31. As a result, we were not able to implement simple population projections between censuses, as the intercensal period was not an integer number of years. In the case when reconstruction was conducted for a period between two censuses referring to different dates we corrected the population of the second census in order to get estimates for the same date as the first. Moving population pyramids from date to date, we used a backward projection by one whole year and a linear interpolation.

A summary of what life tables and census populations were used for the different reconstruction periods is presented in Table 1 . 
Table 1:

Reference census populations and life tables used in reconstructing periods

\begin{tabular}{lll}
\hline Period & Life tables used & Census populations used \\
\hline $\mathbf{1 8 7 0 - 1 8 8 0}$ & $1868 / 71^{\mathrm{a}}, 1879 / 82^{\mathrm{a}}$ & $31.12 .1869,31.12 .1880$ \\
$\mathbf{1 8 8 1 - 1 8 9 0}$ & $1879 / 82^{\mathrm{a}}, 1889 / 92^{\mathrm{a}}$ & $31.12 .1880,31.12 .1890$ \\
$\mathbf{1 8 9 1 - 1 9 0 0}$ & $1889 / 92^{\mathrm{a}}, 1899 / 1902^{\mathrm{a}}$ & $31.12 .1890,31.12 .1900$ \\
$\mathbf{1 9 0 1 - 1 9 1 0}$ & $1899 / 1902^{\mathrm{a}}, 1909 / 12^{\mathrm{a}}$ & $31.12 .1900,31.12 .1910$ \\
$\mathbf{1 9 1 1 - 1 9 2 2}{ }^{\mathrm{b}}$ & $1909 / 12^{\mathrm{a}}, 1926 / 30^{\mathrm{c}}, 1930 / 33^{\mathrm{c}}$ & $31.12 .1910,07.03 .1923^{\mathrm{d}}$ \\
$\mathbf{0 3 . 1 9 2 3 - 0 3 . 1 9 3 4}$ & $1926 / 30,1930 / 33,1931 / 35$ & $07.03 .1923,22.03 .1934^{\mathrm{d}}$ \\
$\mathbf{0 3 . 1 9 3 4 - 0 3 . 1 9 3 9}$ & $1931 / 35,1936 / 1940$ & $22.03 .1934,17.05 .1939^{\mathrm{d}}$ \\
\hline
\end{tabular}

Notes: ${ }^{a}$ Life table corresponds to the territory of the Austrian Alpenländer;

${ }^{\mathrm{b}}$ Age-sex structures were reconstructed for the pre-war years only (1911-1914);

${ }^{\mathrm{c}}$ Used to extrapolate the right-hand side reference life table of the period (i.e., 1923);

${ }^{\mathrm{d}}$ Census population was projected backward to the date of the previous census.

\subsection{Reference life tables}

In our method for reconstructing the life tables, we rely on reference life tables available from the literature for periods adjacent to the censuses. Therefore, we need to decide which life tables to choose for these reference tables. It must be noted from the very beginning that no life tables are available that would be fully consistent with the present-day territory of Austria for the years prior to 1912. Hence, for our purposes we chose life tables that have the closest possible acceptable geographical congruity with that of the present-day Austria.

The Human Life-Table Database (http://www.lifetable.de) provides life tables with different geographical coverage for periods 1865/75, 1868/71, 1870/80, $1879 / 82,1889 / 92,1899 / 02,1901 / 05,1906 / 10,1909 / 12,1930 / 33$ and also for the post-war period. Abridged life tables are also available from Österreichisches Statistisches Zentralamt (1960) for the periods 1926/30, 1931/35, 1936/40, $1951 / 55$ and $1956 / 58$.

From these sources we used only those life tables which nearly correspond to the current geographical area of Austria and also cover the period which was studied in this work. For periods prior to 1912, we supposed the Austrian Alpenländer to be a good approximation for today's geographical area of Austria. As was mentioned above, Austrian Alpenländer covered most of the present-day Austria (with exception of Burgenland, which comprised about $5 \%$ of population) and also included some adjacent territories (mainly parts of north-eastern Italy and Slovenia). The population of the Austrian Alpenländer was by about $15 \%$ larger compared to that of the present territory of Austria. We took these differences to be relatively small, especially because the mortality on the territory of Alpenländer within and beyond the present-day area of Austria was 
presumably quite similar. This assumption on the similarity of mortality levels in Austria and Austrian Alpenländer was checked based on available deaths statistics, as will be discussed further down in the paper.

Hence, we have chosen to use life tables for the periods 1868/71, 1879/82, 1889/92, 1899/1902, 1909/12 (these life tables refer to the Austrian Alpenländer) and 1926/30,1930/33,1931/35, 1936/40 (the latter ones already cover the present-day territory of Austria). That means, life tables for the periods 1865/75, 1870/80, 1901/05 and 1906/10 were neglected (because of their inclusion of vast eastern areas of Cisleithania with a high mortality not representative of Austria). A list of life tables used for the different periods of interpolation is presented in Table 1.

It is to be noted that Findl (1979), who originally estimated the life tables used here for the period prior to 1912 , had addressed the problems related to data quality, such as age heaping. However, he did not make any corrections for a possible undercount of children and also for a possible overstatement of age at census. Nonetheless, we used his estimates as they are, making only minor improvements in order to extend the highest age of the life table. The rationale behind this was that, firstly, we aimed at producing a series of life tables that was consistent with the estimates available. Secondly, concerning the unexpectedly low counts of children at censuses, this might well be explained by migrations of/with newborn children away from the capital area of the Austro-Hungarian empire, which was also mentioned by Findl himself. One should note, however, that mortality at ages above 80 might well be underestimated as our results of projecting population at old ages from census to census also indicate the existence of overstatement of age at censuses.

Some of the life tables selected for usage were corrected due to minor inaccuracies. In particular, the $\mathrm{L}_{\mathrm{x}}$ functions in the Human Life-Table Database exhibit some erratic variations presumably because they were estimated from $\mathrm{e}_{\mathrm{x}}$ functions published in the original source with only one digit after the comma (e.g., Statistik des Bundesstaates Österreich 1935). Therefore, we recalculated $\mathrm{L}_{\mathrm{x}}$ functions for ages above 1 based on $1_{x}$ functions. Additionally, age-specific death probabilities calculated from the life tables sometimes exhibited unnatural discontinuities (especially at ages around 70 and 90). Therefore, age-specific death probabilities at respective ages were smoothed after taking the logarithms. Here and whenever necessary, we used moving average smoothing with a fiveyear time frame. In most life tables for the years before 1930, the table functions were available for ages below 90 only. In such cases we extended the table functions until the age of 100 using parabolic extrapolation of the logit function of $1_{x}$.

As mentioned above, only abridged data on death rates were available for the periods 1926/30,1931/35 and 1936/40. Hence, we reconstructed full life tables in this case using the following approach. We based our reconstruction on the life table for 1930/33 which seemed to be of high quality. The detailed age structure 
from this life table was taken as a standard for the purpose of decomposing the abridged rates into rates for one-year age intervals. Abridged functions were obtained from the 1930/33 table and detailed tables reconstruction was made in a way that the ratios of the detailed table's functions to linear interpolations from the abridged tables were the same as for the 1930/33 table. Finally, logarithms of death rates at ages above 30 were smoothed in order to eliminate minor discontinuities.

\subsection{Vital statistics}

For interpolating life tables and population for intercensal years as well as for estimating life tables for years prior to the first modern census, we have used data on deaths (rates as well as numbers) and births (numbers).

Crude death rates and infant mortality rates (both sexes combined only) are available from a Statistics Austria publication (Statistik Austria 2005, Table 1.01). From the same source (Table 1.02) data on births and on deaths by sex for the present-day geographical area of the country are available. The Vienna Institute of Demography has collected a rich dataset on historical demography of Austria, which has not been published, however. We used data on infant deaths and on the total number of deaths since 1819 for the Austrian Alpenländer (data available by sex since 1819, by age from 1830 and also by sex and age from 1851 on) from this data collection in order to improve the accuracy of the life table interpolations and also to estimate the life tables prior to 1870 . Data available by single years of age are, in fact, subject to a minor age heaping. However, we do not smooth the original data or otherwise improve it, because in the interpolation method we used consequences of the age heaping are compensated for as a by-product of the method. Tabulations of the Austrian Alpenländer population by sex, of deaths by sex and of infant deaths are also available at Gisser (1979). A detailed description of available data on deaths is presented in Table 2. 
Table 2:

Availability of data on deaths

\begin{tabular}{|c|c|c|c|}
\hline Period & Type of data & Age grouping & $\begin{array}{l}\text { Geographic } \\
\text { coverage }\end{array}$ \\
\hline 1819-29 & $\begin{array}{l}\text { Total deaths by sex (no age) } \\
\text { Infant deaths for total population (no sex) }\end{array}$ & no age & $\begin{array}{l}\text { Austrian } \\
\text { Alpenländer }\end{array}$ \\
\hline 1830-50 & Deaths by age groups (no sex) & $\begin{array}{l}0,1-3,4-19,20-39,40- \\
59,60-79,80-99,100+\end{array}$ & $\begin{array}{l}\text { Austrian } \\
\text { Alpenländer }\end{array}$ \\
\hline $1851-55$ & $\begin{array}{l}\text { Deaths by age and sex for administrative } \\
\text { years (Nov-Oct) }\end{array}$ & $0,1, \ldots, 99,100+$ & $\begin{array}{l}\text { Austrian } \\
\text { Alpenländer }\end{array}$ \\
\hline 1855 & Deaths by age and sex for Nov-Dec & $0,1, \ldots, 99,100+$ & $\begin{array}{l}\text { Austrian } \\
\text { Alpenländer }\end{array}$ \\
\hline $1856-94$ & $\begin{array}{l}\text { Deaths by age and sex for calendar years } \\
\text { (Jan-Dec) }\end{array}$ & $0,1, \ldots, 99,100+$ & $\begin{array}{l}\text { Austrian } \\
\text { Alpenländer }\end{array}$ \\
\hline 1895-97 & $\begin{array}{l}\text { Deaths by age, Lexis triangle and sex for } \\
\text { calendar years (Jan-Dec) }\end{array}$ & $0,1, \ldots, 90+$ & $\begin{array}{l}\text { Austrian } \\
\text { Alpenländer }\end{array}$ \\
\hline 1898 & $\begin{array}{l}\text { Deaths by age, Lexis triangle and sex for } \\
\text { calendar years (Jan-Dec) }\end{array}$ & $0,1, \ldots, 99+$ & $\begin{array}{l}\text { Austrian } \\
\text { Alpenländer }\end{array}$ \\
\hline 1899-1902 & $\begin{array}{l}\text { Deaths by age and sex for calendar years } \\
\text { (Jan-Dec) }\end{array}$ & $0,1, \ldots, 99+$ & $\begin{array}{l}\text { Austrian } \\
\text { Alpenländer }\end{array}$ \\
\hline 1903-12 & $\begin{array}{l}\text { Deaths by age and sex for calendar years } \\
\text { (Jan-Dec) }\end{array}$ & $0,1, \ldots, 98+$ & $\begin{array}{l}\text { Austrian } \\
\text { Alpenländer }\end{array}$ \\
\hline 1913 & $\begin{array}{l}\text { Deaths by age (see grouping) and sex for } \\
\text { calendar years (Jan-Dec) }\end{array}$ & $\begin{array}{l}0,1, \ldots, 69,70-74,75- \\
79, \ldots, 95-99,100+\end{array}$ & $\begin{array}{l}\text { Austrian } \\
\text { Alpenländer }\end{array}$ \\
\hline 1919 & Deaths by sex & no age & $\begin{array}{l}\text { Austria without } \\
\text { Burgenland }\end{array}$ \\
\hline $1920-25$ & Total deaths by age (no sex) & $\begin{array}{l}0-4,5-14,15-29,30-49 \\
50-69,70+\end{array}$ & Austria \\
\hline 1926 & Deaths by age and sex & $0,1, \ldots, 98,99+$ & Austria \\
\hline 1927-31 & Deaths by age, Lexis triangle and sex & $0,1, \ldots, 99,100+$ & Austria \\
\hline 1932 & Deaths by age and sex & $0,1, \ldots, 98,99+$ & Austria \\
\hline $1933-44$ & $\begin{array}{l}\text { Deaths by age, Lexis triangle and sex (no } \\
\text { data at ages above } 87 \text { in 1943) }\end{array}$ & $0,1, \ldots, 99,100+$ & Austria \\
\hline $\begin{array}{l}1945, \\
1946\end{array}$ & Deaths by age and sex & $0,1, \ldots, 94,95+$ & Austria \\
\hline $1947-51$ & $\begin{array}{l}\text { Deaths by age, Lexis triangle and sex (no } \\
\text { data at ages above } 87 \text { in 1943) }\end{array}$ & $0,1, \ldots, 99,100+$ & Austria \\
\hline $\begin{array}{l}\text { 1871- } \\
\text { present }\end{array}$ & Total deaths by sex & no age & Austria \\
\hline 1871-1900 & $\begin{array}{l}\text { Infant deaths without Burgenland (without } \\
\text { sex) }\end{array}$ & - & Austria \\
\hline 1901-25 & Infant deaths (without sex) & - & Austria \\
\hline $\begin{array}{l}\text { 1926- } \\
\text { present }\end{array}$ & Infant deaths by sex & - & Austria \\
\hline
\end{tabular}




\section{Methodology}

Historical reconstruction methods published in the demographic literature vary from author to author and reflect particular problems with data availability and the research agenda. In any case, such reconstructions are based on certain population balances. Most generally, a population balance implies that the population change must equal the natural increase, i.e., births minus deaths, plus net migration. The direct use of such balances is limited though, due to missing data or poor data quality (birth cohorts reported at different censuses may not be fully consistent because of different census coverages or age misreporting). In case data are available for the population and for the number of deaths, the back projection by Wrigley and Schofield (1982) or the inverse projection by Lee (1974) can be useful. These methods, however, are based on a fully consistent data series for vital events and population and simplify mortality, migration and fertility schedules by using model profiles. Similar concerns apply to an analogous method based on aggregate models and population balances (Ediev 2001). In our study, on the one hand, we rely on data series which are not fully consistent (data on deaths prior to 1913 refer to the Austrian Alpenländer, which differ somewhat from present-day Austria, as discussed above). On the other hand, we have quite a rich collection of data for the period after 1870, which allows an estimation of mortality profiles without assuming some model patterns. For these reasons we do not apply one of the aforementioned methods here. Instead, we develop a special interpolation procedure for life tables and apply population balances to reconstruct net migration and population dynamics. In a sense, our interpolation technique (described further down) is close to that used in constructing life tables for the Human Mortality Database (http://www.mortality.org/). However, there are two main differences. Firstly, due to the aforementioned problems with geographical congruity, we do not use death numbers directly. We rather use them to interpolate the dynamics of life table functions based on already available reference life tables. Secondly, instead of distributing net migration between censuses evenly along birth cohorts' lines, we distribute them along calendar time for each age separately (we find this approach more relevant as migration shows significant age-specific differentials rather than birth-cohort-specific ones).

For the period starting with 1870 we have ready population age-sex pyramids for census dates and life tables referring to the adjacent periods. Hence, we have developed an interpolation approach for this period, in order to get time series of life tables and of population structures consistent with estimates already available. For life tables referring to years prior to 1870 , we have developed a separate regression approach based on the results we obtained for 1870-1910.

We begin this section by describing the methodology used for the period starting from 1870. Later on we proceed with describing the regression approach applied for the period prior to 1870 . 


\subsection{Interpolation of population structure and of life tables for the period after the first modern census (1870-1940)}

We follow two main tasks in developing the interpolating technique. Firstly, the technique is deemed to be as robust as possible. Secondly, we use as much initial data as possible. As the available data are of different origin and sometimes not fully consistent with the current territory of Austria, we perform the interpolation in several steps. A detailed description of the method follows below and a stylised reflection of the method is presented in Figure 1.

Figure 1:

Stylised scheme of the method for interpolating life tables and population age composition in the period between two consecutive censuses (the method is applied to both sexes separately)

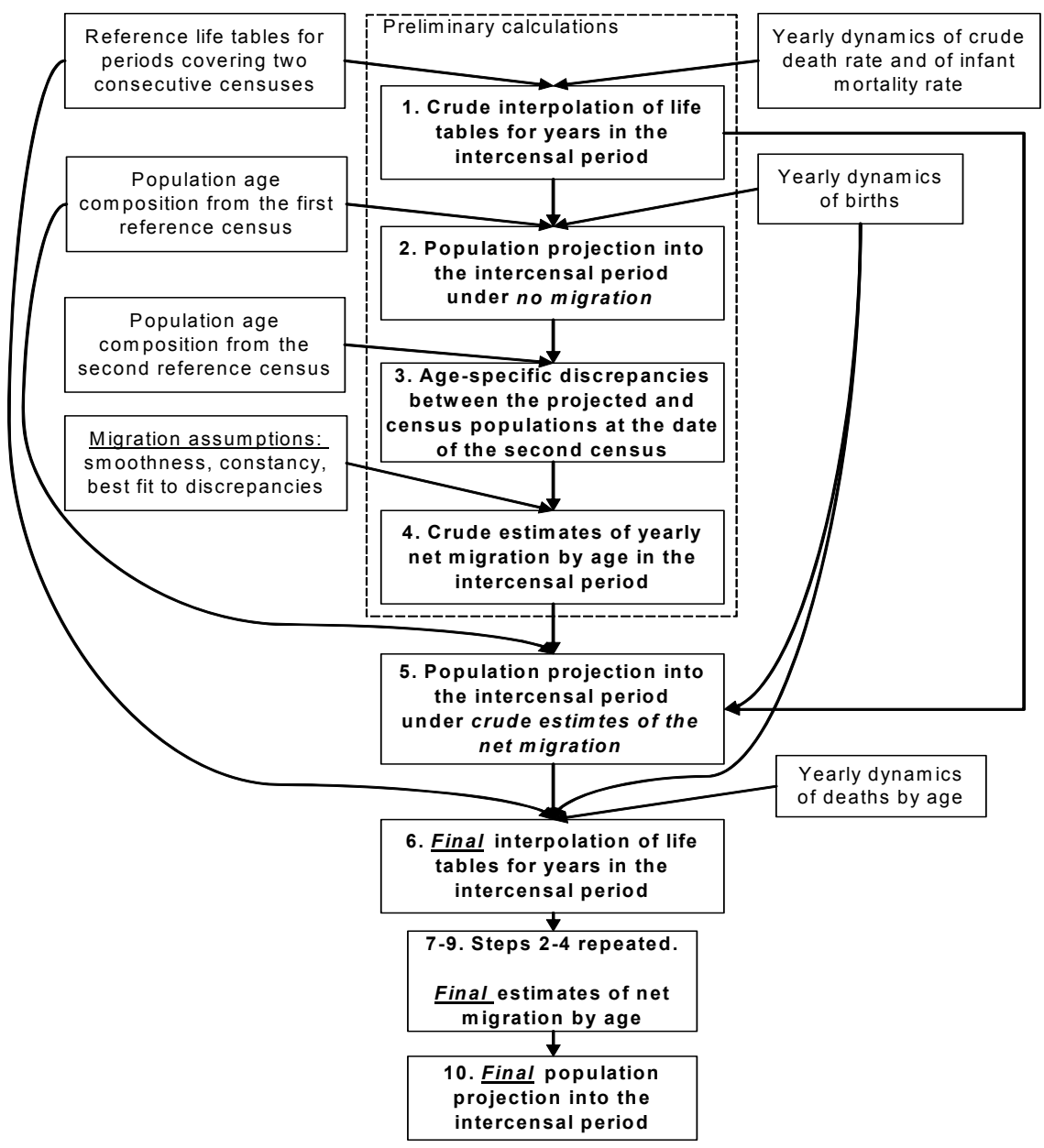




\subsubsection{Crude reconstruction of life tables. Interpolation- correction technique}

At the first step, we obtain crude estimates of life tables between the reference years. Central points of time periods covered by available life tables are used as reference years for interpolations. We calculate age-specific death rates from the life table functions and get interpolations of these rates consistent with vital statistics data available. In particular, yearly changes in mortality in the first age group (0-1 years) are taken to be proportional to changes in the infant mortality rate available from the aforementioned demographic yearbook by Statistics Austria. The dynamics of death rates at ages above one is interpolated using the crude death rate dynamics taken from the same publication. In this and other cases of interpolating a demographic variable (say, $Y$ ) based on the dynamics of another-reference - variable (say, $Z$ ), we use the following linear interpolationcorrection technique. First, we calculate simple linear interpolations in the period between reference years:

$$
\begin{aligned}
Y^{*}{ }_{t} & =Y_{t 0}+\left(Y_{t 1}-Y_{t 0}\right) \cdot \frac{t-t_{0}}{t_{1}-t_{0}}, \\
Z^{*}{ }_{t} & =Z_{t 0}+\left(Z_{t 1}-Z_{t 0}\right) \cdot \frac{t-t_{0}}{t_{1}-t_{0}},
\end{aligned}
$$

where $t_{0}, t_{1}$ are the reference years at the beginning and end of the reconstruction period and $Y^{*}{ }_{t}, Z^{*}{ }_{t}$ are the linear interpolates. Afterwards, we interpolate the value of the variable of interest, multiplying its linear interpolate by the ratio of the reference variable's value to its own linear interpolate:

$$
\hat{Y}_{t}=Y^{*}{ }_{t} \cdot \frac{Z_{t}}{Z^{*}{ }_{t}} \text {. }
$$

By this way we are able to both match the rates at reference years and use available information on mortality dynamics between the reference years.

After obtaining the age-specific death rates, we calculate life table functions for all years in the interpolation period using traditional methods (e.g., Chiang 1984; in the first age interval we use Chiang's $a$ method with values of $a_{0}$ linearly interpolated between reference years). 
Figure 2:

Discrepancies between projection under no migration assumption and census data on Dec. 31, 1880. Males, crude estimates for death rates are applied

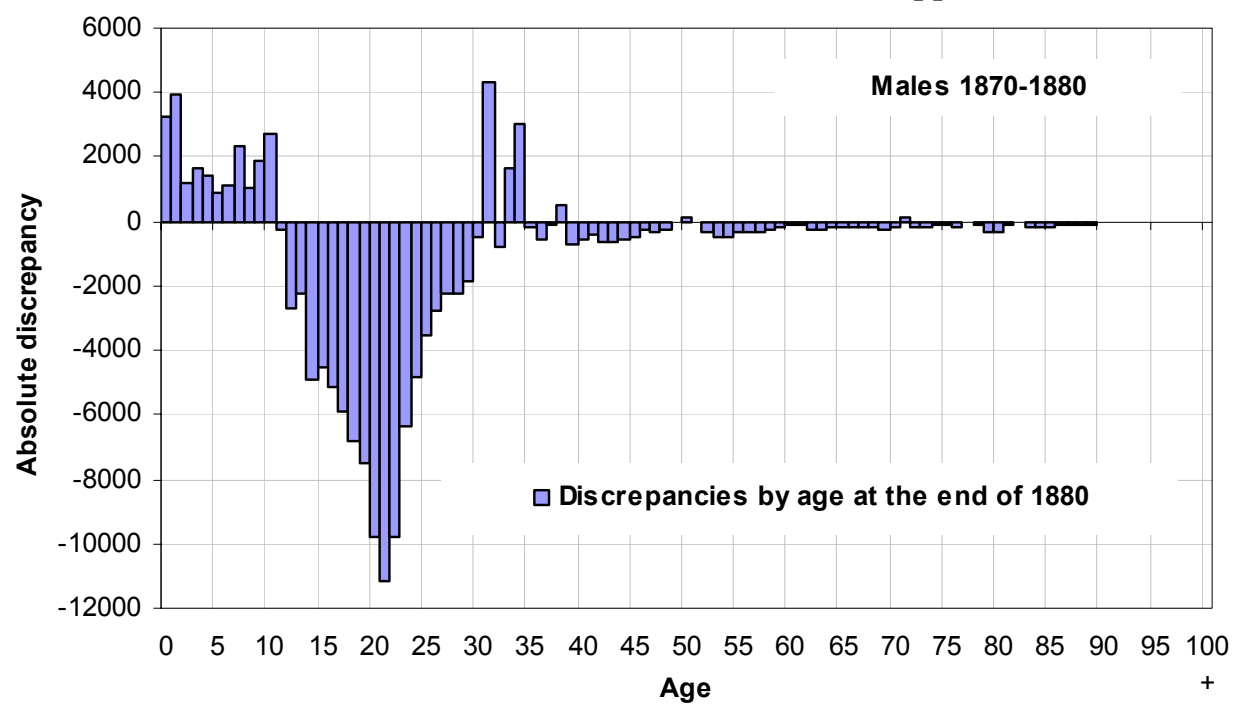

\subsubsection{Crude reconstruction of net migration and of population dynamics}

After getting crude estimates for life tables, we obtain crude estimates of net migration by age. To do so, we project the population age structure from the first reference year of the interpolation interval to the next reference year using census data for the age structure at the beginning of the interval, reconstructed life tables, births statistics, and applying no migration. At ages above zero the projection technique is the same as in the component method, while for the first age group we use births statistics in order to obtain the live population in the first age segment from the births in the preceding year.

Apparently, the projection described results in a final population age structure inconsistent with census data for the end of the interpolation interval. A characteristic example of discrepancies between the projection and census population is presented in Figure 2. We attribute this inconsistency to the effect of net migration between censuses. Numerical analysis suggests that the age pattern of discrepancies between the census data and the projection is similar to a pattern generated by constant migration with a concentration of migrants at young working ages. Hence, we look for such constant age profiles of the net migration between censuses, which would have resulted in the discrepancies obtained after comparing the census data to the projection results (a special approach was applied to the period 1934/38 due to massive population movements caused by the Anschluss as it will be described further down). Age-specific yearly net 
migrations necessary to explain the discrepancies are found as a solution of the optimisation problem with the following goal function, which reflects the necessity for both minimising the discrepancy with census data at the end of the interpolation interval and for maximising the smoothness of the age profile for net migration:

$$
Z=\sum_{x=0}^{100} \varepsilon_{x}{ }^{2}+\sum_{x=2}^{100} v_{x}{ }^{2} \rightarrow \min ,
$$

where $\varepsilon_{x}$ are age-specific projection deviations from the census figures at the end of the interpolation interval and $v_{x}$ are age-specific annual net migration numbers. Note that minimising the second sum in Eq. (4) is equivalent to minimising the variance of net migration at ages above one. Hence, in addition to the necessity of explaining the intercensal population dynamics, we use smoothness as another important feature of the net migration age profile. Note, however, that we have excluded the first two age groups from the smoothness additive in (4), because reconstruction results show sharp discontinuity at these ages (this discontinuity, possibly related to biases in the original data, is discussed further down).

Our assumptions about net migration, albeit simplistic, seem to be fit enough for the purposes of this work. This view is supported, first of all, by the small relative magnitude of the net migration estimates obtained. Additionally, the age profiles of net migration estimates do not change much from one intercensal period to another and are clearly interpretable. Figure 3, for example, presents yearly net migration estimates obtained by solving (4) for the period 1870-1880, for the male population. One may note that most net migrations occurred at young working ages, as might be expected. Net migration estimates at old ages are of small magnitude and may reflect-apart from actual migrations-minor inconsistencies in reference and estimated life tables and population structures. Surprisingly, we have obtained significant negative estimates for net migration at the youngest age groups, which, however, is balanced by positive estimates at the following childhood ages. At the current stage we cannot provide a full explanation for this finding, although some hypothetical causes may be proposed. Firstly, net migration estimates at young age might reflect an overestimation of live births and/or underestimation of children in censuses. Another cause might be related to age overstatement at census. It has been shown elsewhere (Ediev 2003) for historical census data, that the age of children stated at a census might be affected by heaping to the nearest 'round' number of months. Thus, 10- or 11months-aged children might be reported as one-year-old children, which might result in underestimation of the population below age one and in overestimation of the number of children above that age. Such distortions might result in 'net migrations' of the same age profile as we have obtained. In the case of Austria, however, this effect would be limited because the age of census respondents was 
calculated from their date/year of birth. It is also quite likely that families or single parents with newborns temporarily migrated or sent their children from Austria (as it is today) to elsewhere within Austria-Hungary. This view is supported by the significantly high numbers of illegitimate births and also of children given to the Vienna orphanage in the 19th century (rich descriptive and numerical evidence to be found in Pawlowsky 2001). Similar findings of children's deficit at census counts were reported by Findl (1979) who also concluded by assuming a possible undercounting of children at censuses and also the likelihood of out-migration of children born illegitimately. Whatever the real explanation for the estimates we have obtained, they seem to be a reflection of some population movements and regularities rather than random distortions caused by methodical faults.

\section{Figure 3:}

Final results of net migration reconstruction. Yearly net migration by age in 1870-1880, males

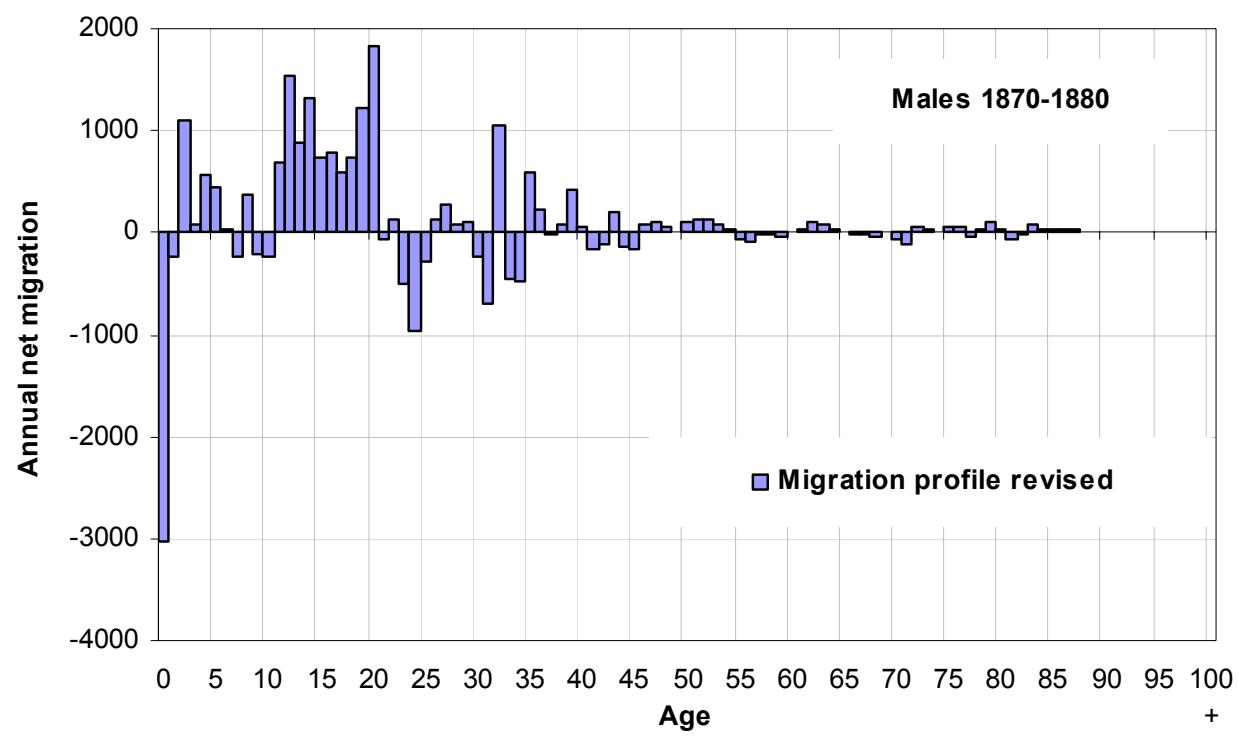

Taking the original life tables as reliable reference estimates, these regularities may not significantly affect our life table interpolations. Therefore, taking into account the scarcity of available migration data and the supplementary role of migration estimates for interpolations of life tables and of population structure, we accepted the simplistic estimates of migration flows as sufficient for the purposes of the work.

Residual discrepancies not explained by the reconstructed net migration flows were less than two per cent for most age groups, except for upper age groups. For ages above 80 the absolute magnitudes of unexplained discrepancy were small, but they were high on a percentage basis - up to a third for some periods at ages 
above 95-due to small population sizes at upper age groups. Following Findl (1979), we also suggest that age over-reporting at census might be a cause of discrepancies between censuses and projections we get. Apparently, this might result in mortality underestimation for those ages. However, we do not correct for these possible biases in order to get time series consistent with reference life tables and census population structures.

After getting the crude estimates for net migration, we use them to obtain crude reconstructions of age structure dynamics, taking into account both the survival rates from the first census year and the net migration estimates in between the censuses.

\subsubsection{Final reconstruction of life tables, of net migration and of population dynamics}

Crude population estimates are used to improve the accuracy of life tables' reconstruction. To do so, we use the data on deaths by age and sex collected by the Vienna Institute of Demography. As mentioned above, the geographical coverage of the dataset is not completely consistent with the current territory of Austria and thus with the geographical reference of the census data used in the work (see Table 2). Therefore, in spite of directly using death rates derived from the deaths statistics, we use the death rates to improve the quality of interpolations applying the same linear interpolation-correction technique (1)-(3) as described above. Due to the necessity to smooth the age-specific death rates, this general approach was slightly modified at different age groups as described below.

At the first age group, we start by estimating the following biased infant mortality rates:

$$
\widetilde{q}_{0, t}=\frac{3 D_{0, t}}{B_{t-1}+2 B_{t}}
$$

where $\widetilde{q}_{0, t}$ is the infant mortality rate for year $t, D_{0, t}$ is the number of infant deaths during the year, and $B_{t}$ is the number of births during the year $t$. These rates are biased because denominator and enumerator in (5) may have different geographic coverage. Therefore it is their dynamics rather than the absolute value which is used in reconstructing. The dynamics of these rates are used to obtain interpolations of the death rate at the first age group using the linear interpolationcorrection technique (1)-(3).

For ages 1 to 5 we use a similar approach applying the corresponding biased age-specific death rates: 


$$
\tilde{m}_{x, t}=\frac{2 D_{x, t}}{N_{x, t}+N_{x, t+1}},
$$

where $N_{x, t}$ is the population at age $x$ at time $t$ and $D_{x, t}$ is the number of deaths at age $x$ during the year $t$. For the years 1920-1925 we have no data on deaths by single years of age. Therefore, we used death rates for five-year age groups for the purposes of interpolation at ages below six.

For ages 6 to 85 the death numbers and population numbers at corresponding ages are preliminarily smoothed using moving averages with a nine-year frame. For ages above 85 a single (biased) death rate for the whole age segment 85 and above is used to obtain interpolations of the death rates. After obtaining all interpolations, death rates at ages 20 to 98 are additionally smoothed using fiveyear moving averages.

The age-specific death rates obtained are finally used to recalculate life table functions.

Finally, we re-estimate the net migration and population structure using the improved life tables and the optimisation approach described above. In calculating final estimates for the population age structure, we also distribute residual discrepancies unexplained by migration, in order to obtain continuous population dynamics consistent with the census data. These residual discrepancies are evenly distributed between years in the intercensal period.

As a result of the described multi-stage approach, we obtain estimates for the life tables, age-specific net migration and population age structures for both sexes at all interpolation periods.

\subsubsection{Special procedures applied to particular periods of time}

In this section we describe some specific procedures, which were applied to selected periods due to data omissions, irrelevance of migration assumptions, etc.

Because the net migration estimates for the period 1924/34 were affected to apparent random fluctuations, this random component was supposed to be linked to residual inconsistencies in population estimates obtained by backward projection of the population from the 1934 census (which was done, as discussed in the introduction, in order to synchronise with the date of the previous census). Therefore, before applying the general method of estimating net migration, we fit optimal corrections to the population estimates for 1934, which sum up to zero for the whole population. We consider these corrections as residual inconsistencies of population estimates and do not add them into the net migration estimates.

For the period covering World War I (1911-1922), we have changed the constant net migration assumption in order to delineate between pre-war and postwar years. For the pre-war period (1911-1913) we apply the same net migration 
profile as it was estimated for the preceding period (1901-1910) and get the population age composition by projecting forward from 1910. For the post-war period (1919-1922) we obtain crude estimates of the population age composition by backward projecting from the 1923 census and applying no migration. For the years 1914-1918 we also derive preliminary estimates of life tables for the civilian population using data available on infant mortality and on civilian deaths by sex. Based on these data and on the pre-war trend we first estimated the crude death rate from regression on infant mortality and death numbers and used these estimates for obtaining age-specific death rates using the same interpolationcorrection technique as described above. Hence, estimates for life table functions for the period of World War I are preliminary and only presented here to show the general trends in civilian mortality.

Estimates of population age composition in 1920-1922 are also too simplistic to be presented as reconstructions so they are only used to improve life table estimates. Hence, we have no estimates of the population composition in 19201922.

In the period 1934/38 we supposed it to be unrealistic to apply constant net migration assumption as the Anschluss in March 1938 triggered unprecedented migrations across the border (massive refuge of Jews, net immigration of military, etc.) Therefore, for the period before the invasion, we assumed the net migration to be equal to that estimated for 1923/34, allocating the rest of net migration in the period to the single year preceding the 1939 census.

Another correction to the general procedure concerns interpolation of the death rates (1)-(3) for periods starting from 1911. The problem we have encountered for these periods was that the reference life tables sometimes did not match the reference census dates. In that case we applied the same death rates interpolation technique, using for each particular single year the two life tables available with the closest time coverage.

\subsection{A regression approach to estimate life tables referring to the period prior to the first modern census (1819-1869)}

We also obtained estimates for life tables referring to the years 1819-1869, using a separate approach. For this period, however, we were limited in available data. In particular, we have no reliable reference life tables and population structures for this period. At the same time, a rich data collection on deaths in the Austrian Alpenländer by age and sex is available for the years 1851-1869. Also, data are available for deaths in the Austrian Alpenländer by rough age groupings and both sexes combined for the years 1830-1849. And for the period 1819-1829 data are available for births and deaths by sex as well as on infant deaths but for both sexes combined. This is why we have developed a regression approach to 
estimate life table functions in this period. We estimate all age-specific death rates necessary to derive life table functions from the following regressions:

$$
m_{x, t}=b_{0}+b_{1} M_{1}+b_{2} M_{2}+\ldots+b_{K} M_{K},
$$

where $M_{1}, M_{2}, \ldots, M_{K}$ is the set of regression variables, which vary from one period to another (details follow below) and $b_{0}, b_{1}, b_{2}, \ldots, b_{K}$ are regression parameters, which are estimated from the reconstructed time series of life tables for 1870-1910. The choice of the time period used to estimate regression parameters is determined by the fact that the last pre-war census had been carried out in 1910 and also by the fact that during and after the war births and life table functions changed in a rather unstable fashion. As for the regression variables, three different sets of them are used for the periods 1819-1829, 1830-1850 and 1851-1869, depending on data availability. For the years 1819-1829 we use infant mortality rate and crude death rates for each sex as regression variables. For the years 1830-1850 we add total deaths at ages 1-4, 4-20, 20-40, 40-60, 60-80 and 80 and above, divided by the total population size. Indeed these 'rates' are not events-to-exposure rates. Yet, assuming a relative stability of the population age composition prior to the beginning of the 20th century, we rely on these rates as better predictors of age-specific death rates than the pair of aggregate variables used for the period before 1830 . We use the same set of regression variables for all age-specific death rates and therefore one may expect that the whole set of regression variables should be a good predictor of death rates as variations of the population at different ages and following distortions in 'age-specific' deaths-topopulation ratios should be levelled off by each other. Finally, for the period 1851-1870 detailed death statistics are available and we use the same set of regression variables as for the previous period, but with deaths-to-population ratios calculated separately for each sex. The quality of regressions is good enough as can be seen from the determination coefficients: for infant mortality rates it is close to $100 \%$, and close to or above $90 \%$ for all other death rates, except for rates at older ages. For the simple regression model used for the period 1819-1829 the smallest determination coefficient (16\%) was obtained for the open age interval $100+$. For ages below 60 it was close to or above $90 \%$, though, and for ages $60-99$ it was about $60-70 \%$. For the models used for the period 1830-1870 all determination coefficients were close to or above $95 \%$, except for the open age interval $100+$ and ages $90-99$, were they were close to $65 \%$ and $80 \%$ for males and to $50 \%$ and $70 \%$ for females. 


\section{Validity of the reconstruction}

In this section we discuss the main results of the reconstruction in the context of checking its validity.

As a matter of checking the overall accuracy of the estimates obtained, we have estimated the total number of deaths from reconstructed life tables and population age composition and compared these estimates to those officially available from the Demographic Yearbook of Statistics Austria. Note that we do not use the total number of deaths in deriving our estimates for life tables and for population structures prior to 1912 . Instead, we use only reference life tables and also deaths by age and sex for the Austrian Alpenländer. Our estimates as well as the original estimates by Statistics Austria (termed 'actual' deaths) and also estimates of births by Statistics Austria for 1870-1940 are presented in Figure 4. Apparently there are some discrepancies between actual and estimated deaths. Notably, these discrepancies are in fact observed for most reference years, i.e., these discrepancies originate mainly from the reference life tables and census populations used in our reconstruction rather than from the reconstruction method. Mortality on the present-day territory of Austria was indeed slightly higher than that of the Austrian Alpenländer because the former includes some additional regions in the east with presumably higher mortality (e.g., Burgenland) and does not include some other regions in the west with presumably lower mortality (e.g., South Tyrol). Also, the discrepancies might in part be explained as consequences of smoothing the life table functions, of simplistic migration assumptions and of a different geographical coverage of life tables and deaths statistics. Bearing in mind these factors and also the small magnitude of discrepancies, one may assume the reconstructions thus obtained to be a reliable reflection of historical mortality and population trends in Austria. In any case, the discrepancies seen in Figure 4 are small, both on a percentage basis and compared to the natural increase observed in Austria for the time period addressed. Nonetheless, our estimates for the years prior to 1912 are indeed more relevant to the Austrian Alpenländer which may be considered as merely a good approximate to the present-day territory of Austria.

As mentioned before, we do not directly address the problem of reconstructing the migration flows to and from Austria. In estimating the population age structure, however, we have obtained estimates for average annual net migrations by age for each of the intercensal periods concerned. These estimates are interesting both per se and also in assessing the reliability of population statistics used and of estimates obtained. Figure 5 presents general trends of net migration by sex obtained while reconstructing the age structure dynamics for 1870-1937. One may note the relative stability of net migration estimates, which moderately decreased in 1870-1910, with an average 7400 for males and 8400 for females. World War I and the following dissolution of Austria-Hungary dramatically depressed net migration. Following the Anschluss 
in March 1938, annual net migration dropped even further (our estimates for net emigration during the twelve months following the Anschluss yielded 11400 males and 63900 females).

\section{Figure 4:}

Estimated deaths compared to deaths and births statistics for the Austrian population in 1870-1940

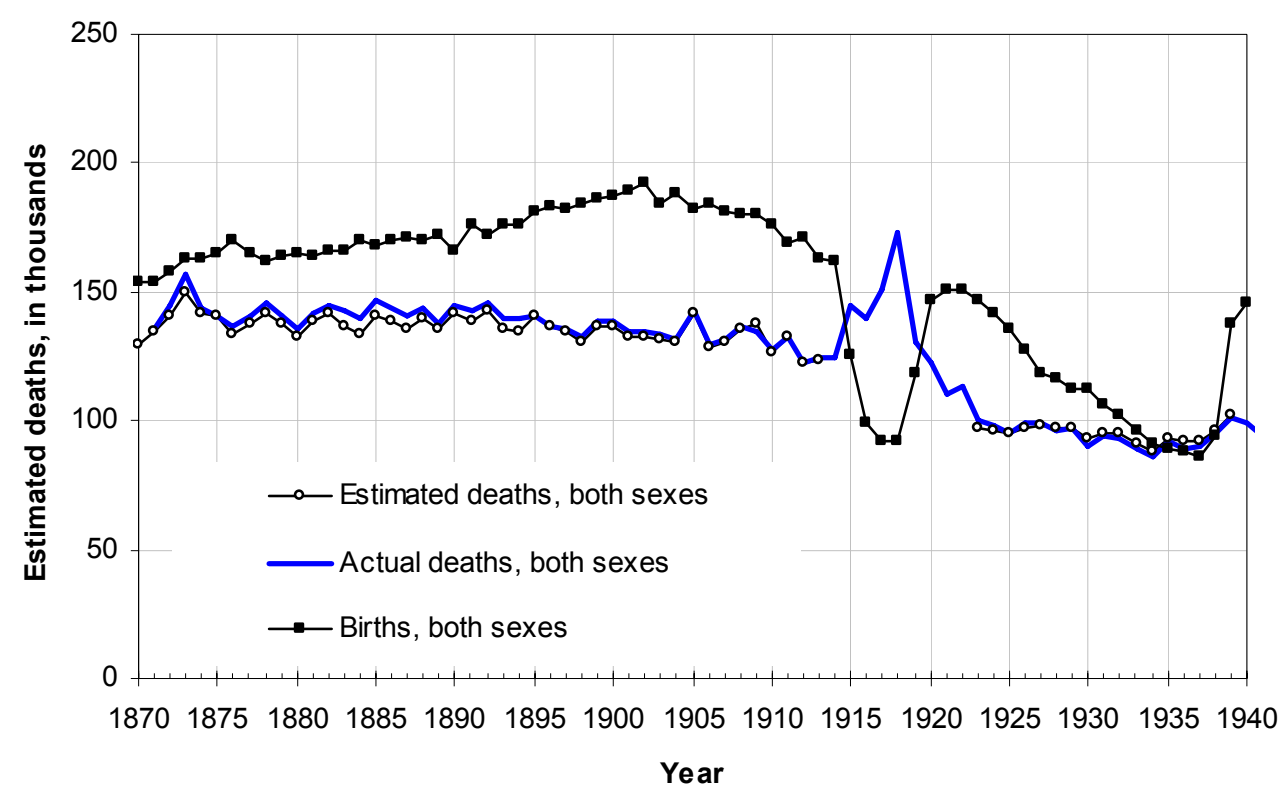

The average annual age composition of net migration estimates for 1870-1910 is presented in Fig 6. Apart from some fluctuations, net migration shows regular age patterns. These patterns are characteristic both for the average annual net migrations presented in the graph and also for all intercensal periods concerned. One should note that in the period covered by the graph Austria was a part (the capital part) of the Austro-Hungarian monarchy. The remarkably high negative net migration in the first age groups followed by a 'recovery' at later childhood ages may reflect migration with newborn children or sending the children outside the central region of the monarchy to their grand-parents. This may have a special importance for illegitimate births as discussed above and elsewhere. Most migrations occurred at young working ages, which was quite 'natural' for the more developed part of the monarchy. Higher net migration at ages around 14 (especially in case of males) seems to be related to the beginning of apprenticeship, upper-secondary schooling and unskilled labour. Significant differences between males and females at ages around 20 may reflect migrations to and from military service in central parts of the monarchy. The age patterns of 
net migration are even more regular and self-explaining if we look at cumulated (from age zero to age $x$ ) net migrations (Figure 7).

Figure 5:

Estimated annual net migration by sex for Austria in 1870-1937 (thousands)

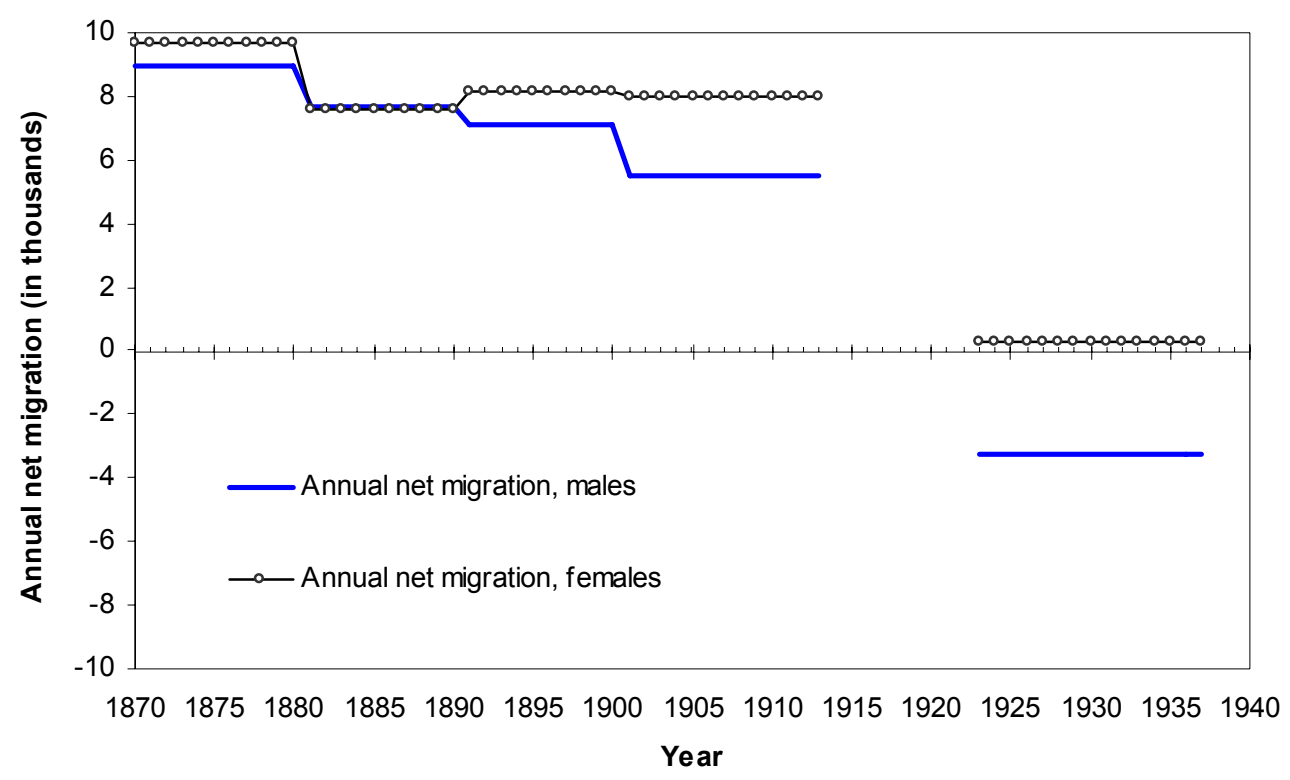

Figure 6:

Estimated average annual net migration by sex and age for Austria in 1870-1910

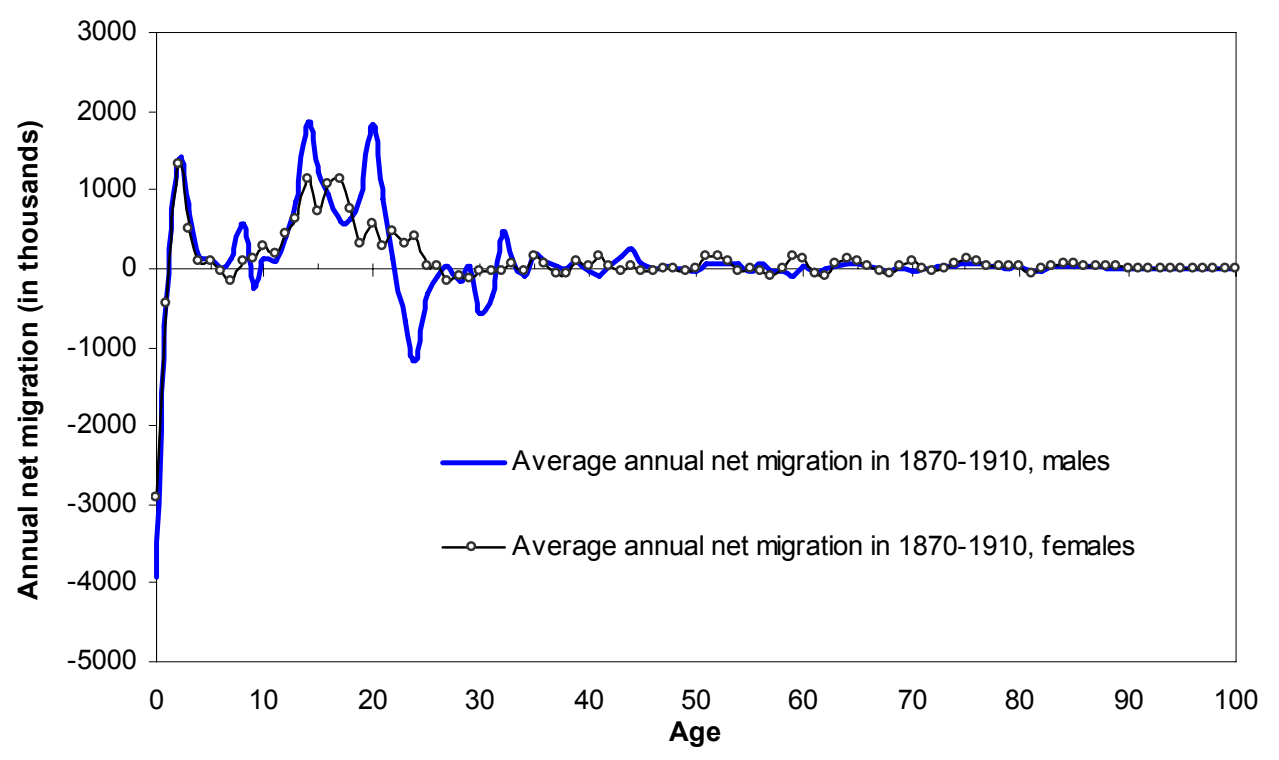


Figure 7:

Estimated average annual net migration by sex for Austria in 1870-1910, cumulated by age

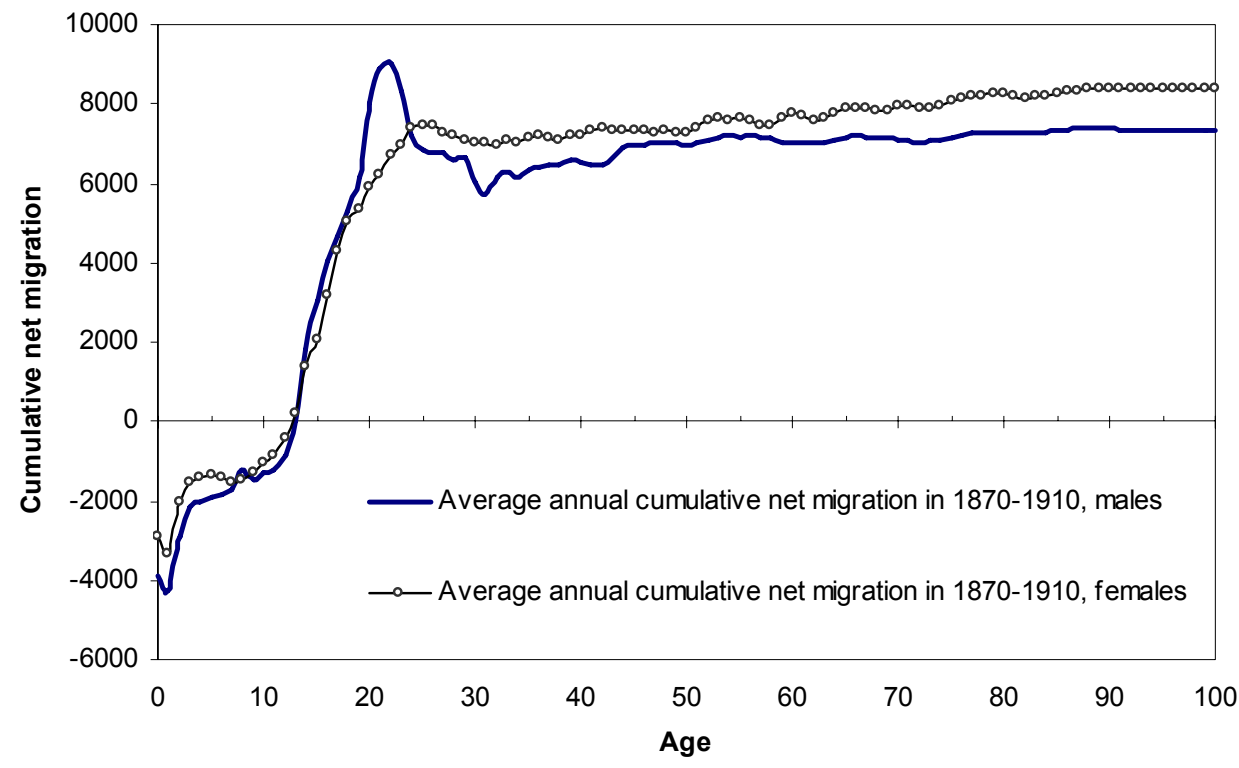

Concluding this section, we may emphasise once again that reliability of the reconstruction results - apart from the richness and good quality of original data-is supported by the small difference between the numbers of deaths estimated from reconstructions and available from vital statistics, as well as by the small relative magnitude and the regular and stable patterns of estimated net migrations.

\section{Reconstruction results}

Here we present general trends in population and mortality in Austria. More detailed results are available at the Data \& Trends section of the website of the Vienna Yearbook of Population Research (http://www.oeaw.ac.at/vid/yearbook).

Figure 8 presents the reconstructed dynamics for the Austrian total population as well as the official estimates for the second half of the $20^{\text {th }}$ century. The significant population growth observed before World War I was interrupted due to war losses, influenza pandemics and also because of a post-war slowing-down and even reversal of the population growth.

Details of these developments are seen in the dynamics of population age-sex structure. In Figures 9 and 10 we present the reconstructed dynamics of population at age groups $0-14,15-64$ and $65+$ for males and females, respectively. The post-World War I divergence of age structures of males and females reflects 
high losses of the male population to the war (see online material at http://www.oeaw.ac.at/vid/yearbook). World War I also had another effect on the population age structure: due to the sharp fall of births during the war, cohorts born in the war period were of extremely low size compared to other adjacent age groups.

It is also apparent from the dynamics of the population age structure that both birth numbers and infant mortality rate experienced a significant decline after the war.

The population growth momentum gained by the mechanics of the demographic transition is clearly seen from the dramatic growth of the young and middle-aged population. In the case of males, however, the population gain at middle ages was offset by severe war losses, which brought a strong gender disparity. This resulted in a strong distortion of the sex ratio in the marriage market. Figure 11 shows the dynamics of the ratio of males to females at ages when more than $80 \%$ of all men and women got married, according the population composition by marriage status in 1910 (Bundeskanzleramt 1975: p. 89, Table 17).

\section{Figure 8:}

Reconstructed dynamics and estimates of the total population of Austria (with current geographic coverage), 1819-2004, as at the beginning of the year, thousands

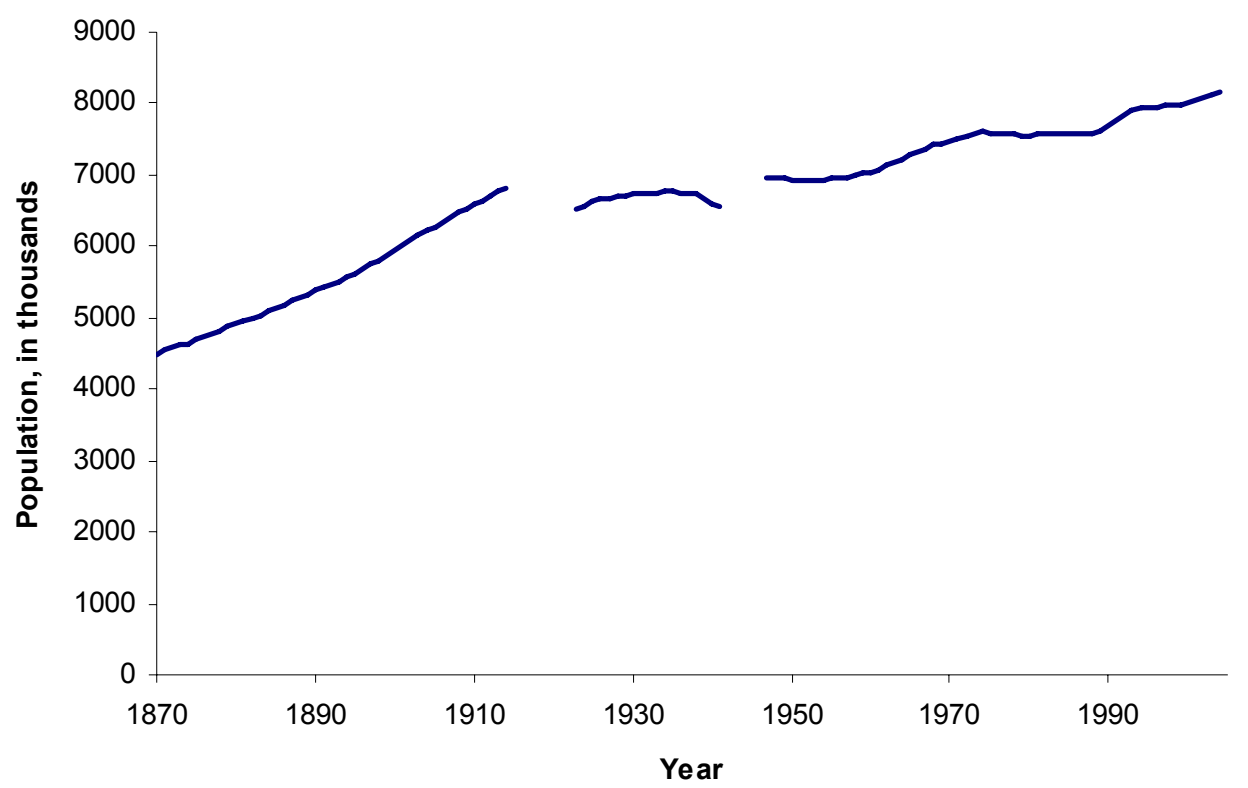


Figure 9:

Reconstructed dynamics of the age structure of the Austrian male population in 1870-1914 and 1923-1940 (current geographical area)

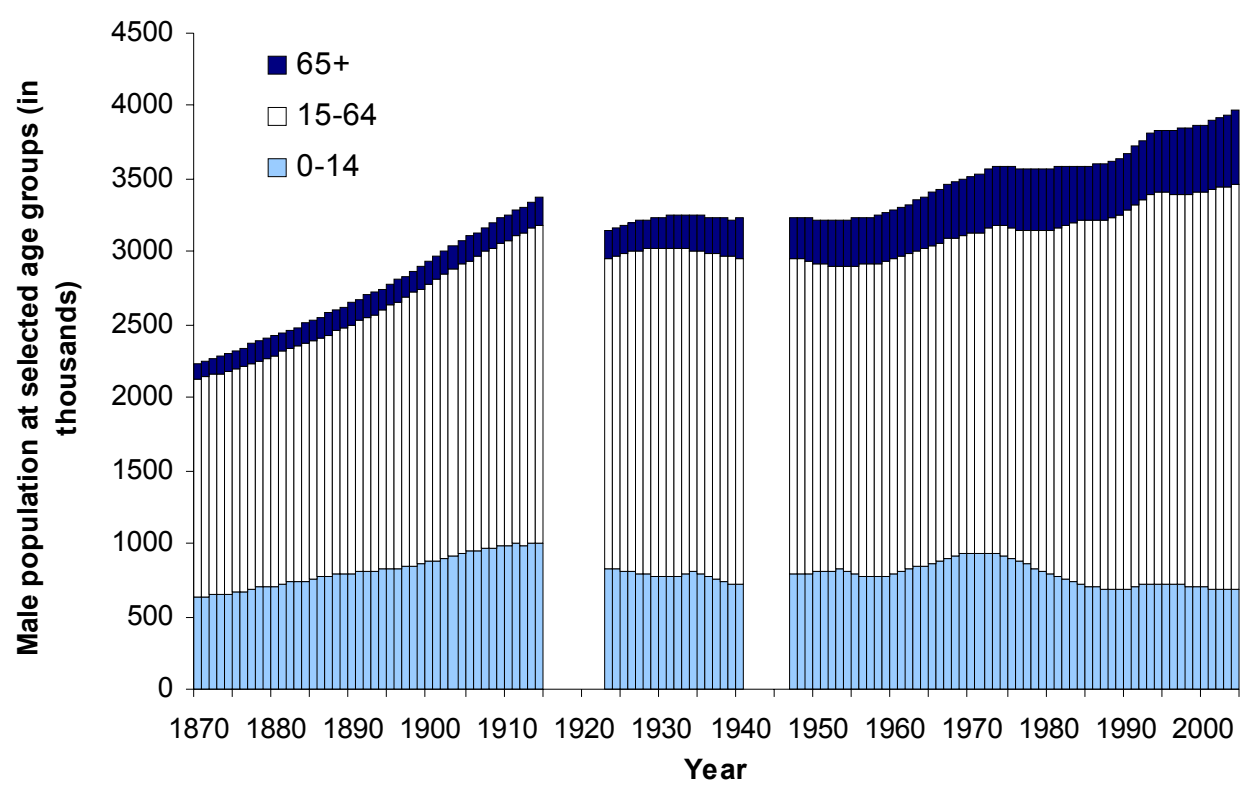

Figure 10:

Reconstructed dynamics of the age structure of the Austrian female population in 1870-1914 and 1923-1940 (current geographical area)

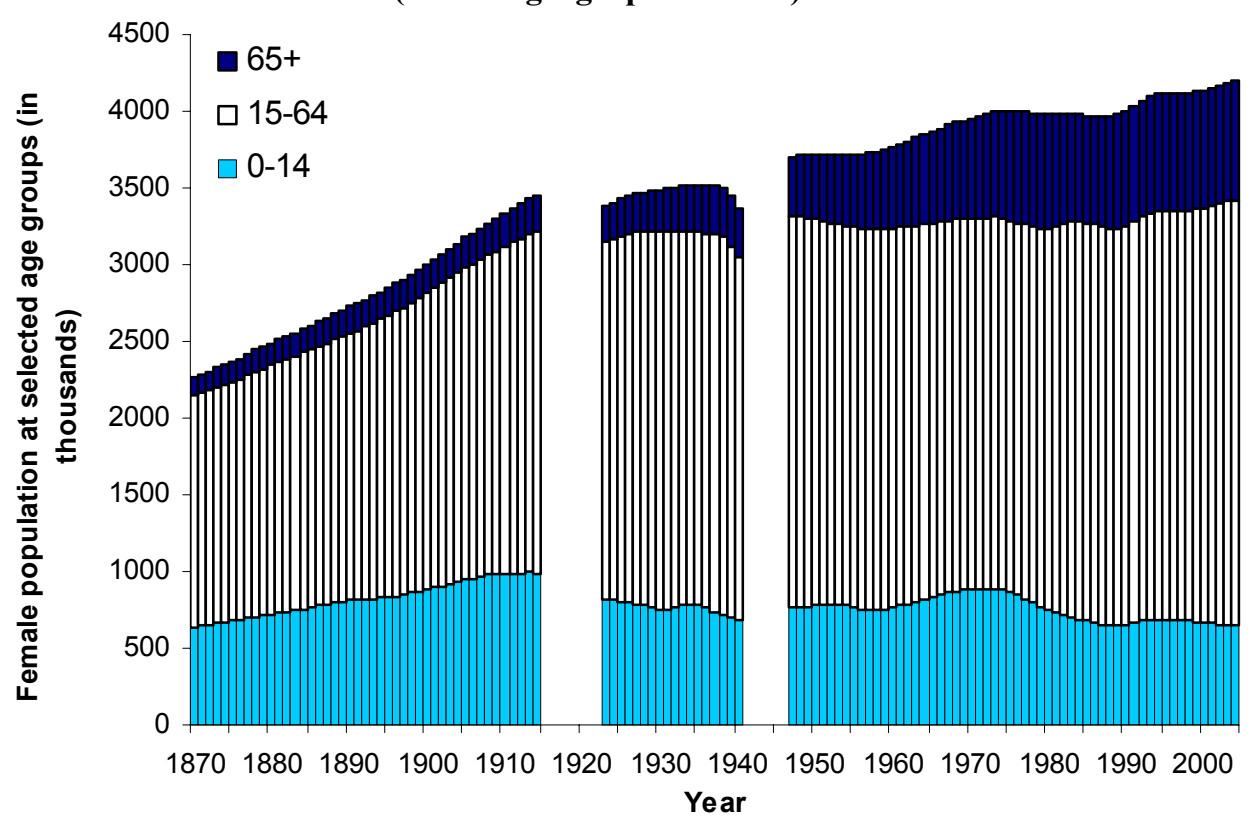


Figure 11:

Reconstructed dynamics of the ratio of males to females at the most important marriage ages

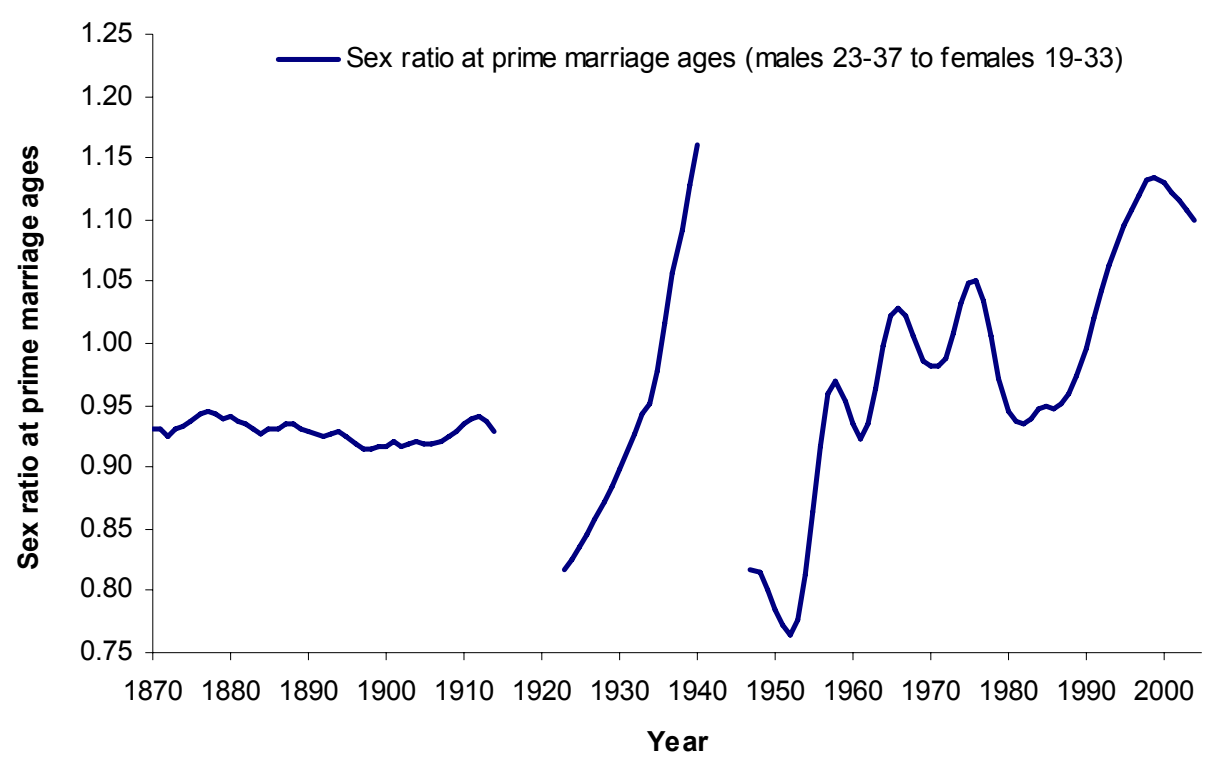

One may note that before the war the sex ratio was stable and slightly in favour of males, resulting in proportions of ever-married males about five per cent higher than that of females (this figure is in good correspondence with the proportions of ever-married persons presented in the aforementioned work for the years 1880 and 1910). This "marriage squeeze" then deteriorated sharply due to war-time losses. Birth decline, however, which started at the beginning of the 20th century, brought an opposite trend in the gender proportions in the marriage market and resulted in the number of potential grooms growing to be in excess of that of potential brides already by the mid-1930s. This trend is related to gender differentials in age at marriage as grooms being older than their brides belonged to more populous birth cohorts. Later on World War II again resulted in a deficit of men, which was gradually recovered after the war. These findings are in accordance with results derived elsewhere from census data on population evermarried (Bundeskanzleramt 1979: pp. 21-23).

Birth dynamics, life expectancy improvements, war losses and migration have shaped the dynamics of dependency ratios as shown in Figure 12. Opposite trends in young and old-age dependency ratios resulted in almost the same total dependency ratio (47\%) by the end of the 20th century as in the late 19th (50\%). 
Figure 12:

Reconstructed dynamics of the dependency ratios of the Austrian population

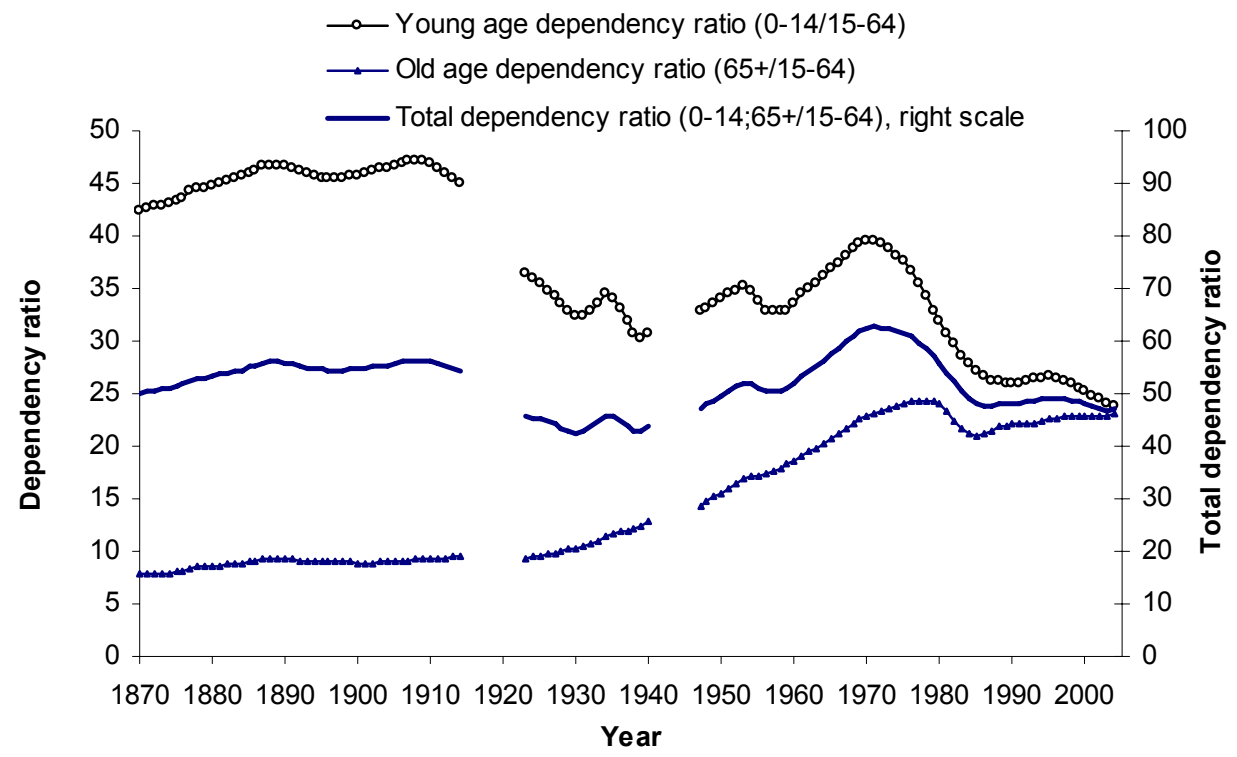

Selected characteristics of reconstructed mortality dynamics are presented in Figures 13-16. Figure 13 presents reconstructed dynamics of life expectancy at birth compared to the life expectancy at birth for Sweden (HMD 2007). As shown elsewhere (Gisser 1979), life expectancy was stagnating during most of the 19th century. In the early 1870 s the life expectancy trend was somewhat depressed due to the last cholera epidemics (1873). Later on, however, life expectancy at birth grew almost linearly up to 67 years in the mid-1950s, when the trend changed and life expectancy proceeded to grow at a slower pace or stagnated. The two world wars had a negative effect on the life expectancy trend. In 1918 it was aggravated due to the influenza pandemic.

The dynamic growth of life expectancy during the late 19th century and first half of the 20th century was in part due to the rapid decline of infant mortality, see Figure 14. Life expectancy at age five (Figure 15) developed more uniformly and life expectancy at old ages started to grow more rapidly in the 1970s only (see Figure 16 for life expectancy at age 65). Years of cholera epidemics $(1832,1836$, $1849,1855,1866$ and 1873) as well as the great famine of 1847 were marked by significant worsening in life expectancy. Surprisingly, a sudden temporary improvement in life expectancy was observed in 1860 . There is no straightforward explanation for this rare event, which at first glance seems to be a statistical artefact. However, a similar sudden decline in mortality in 1860 is observed from Czech data (Srb 2004) and also from data on Sweden. The surprisingly low mortality in 1860 has been discussed elsewhere (Gisser 1979). In fact, the exceptionally low mortality in 1860 was a well-recognised phenomenon 
Figure 13:

Reconstructed dynamics of life expectancy at birth for the Austrian population by sex in comparison with Sweden

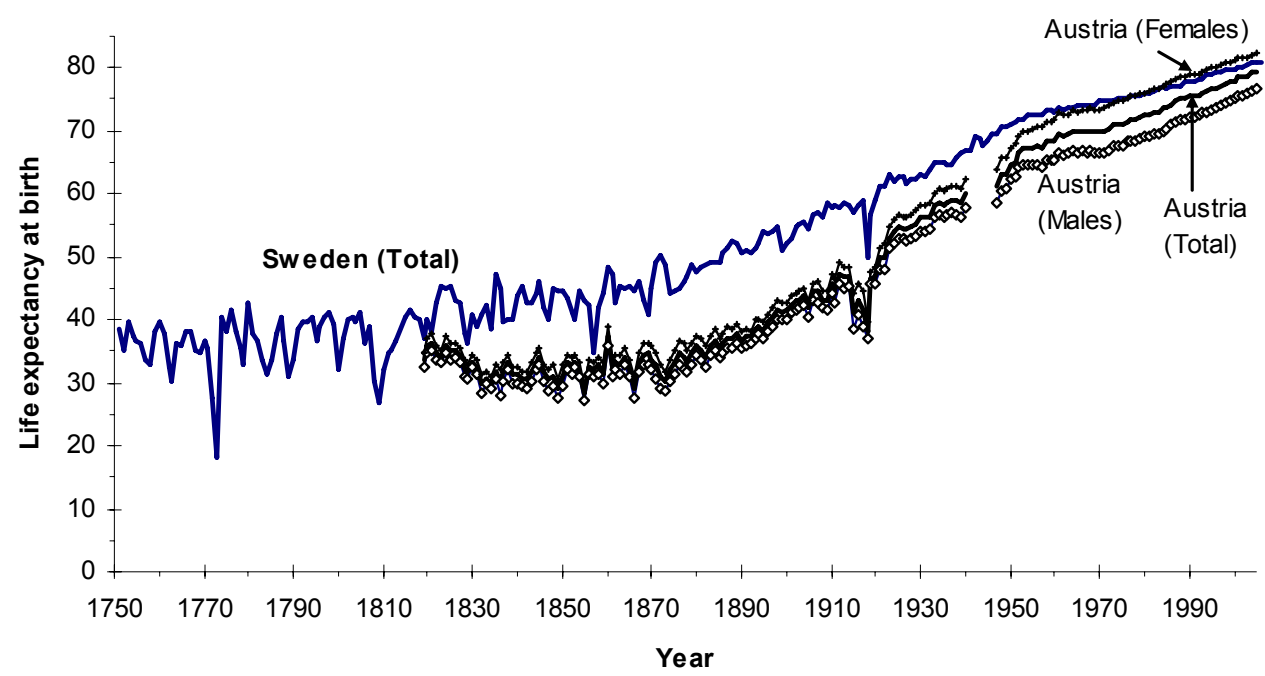

Notes: Estimates for the period of World War I are based on data on civilian deaths only. Data for Sweden (both sexes combined) shown for comparison.

Source: Data for Sweden come from HMD (2007).

Figure 14:

Reconstructed dynamics of infant mortality by sex for Austria (per 1000 births)

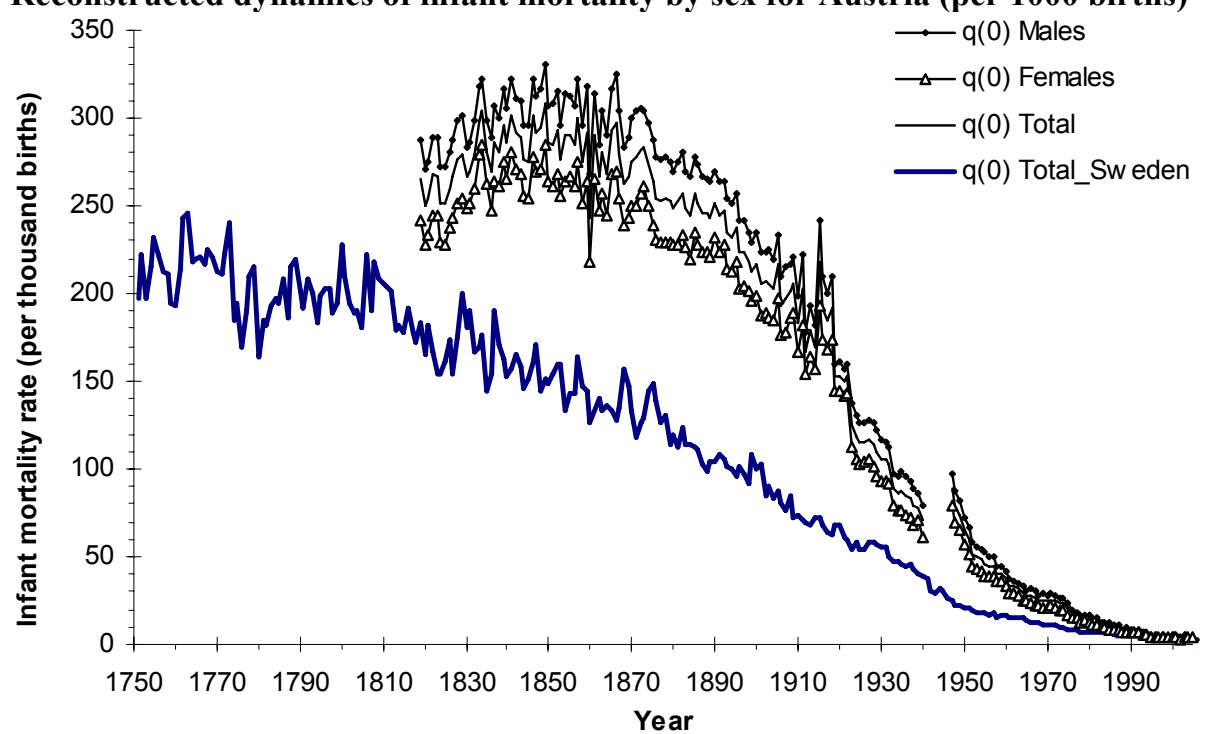

Notes: Estimates for the period of World War I are based on data on civilian deaths only. Data for Sweden (both sexes combined) shown for comparison. 
Figure 15:

Reconstructed dynamics of life expectancy at age five for the Austrian population by sex

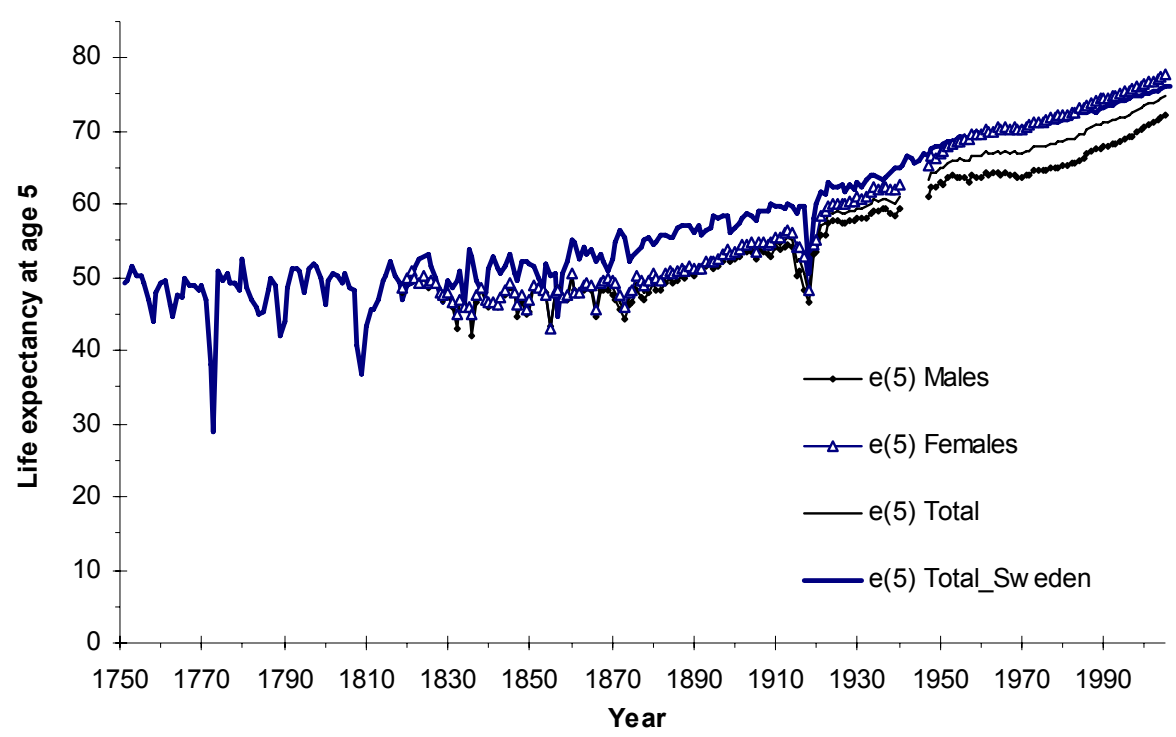

Notes: Estimates for the period of World War I are based on data on civilian deaths only. Data for Sweden (both sexes combined) shown for comparison.

Figure 16:

Reconstructed dynamics of life expectancy at age 65 for the Austrian population by sex

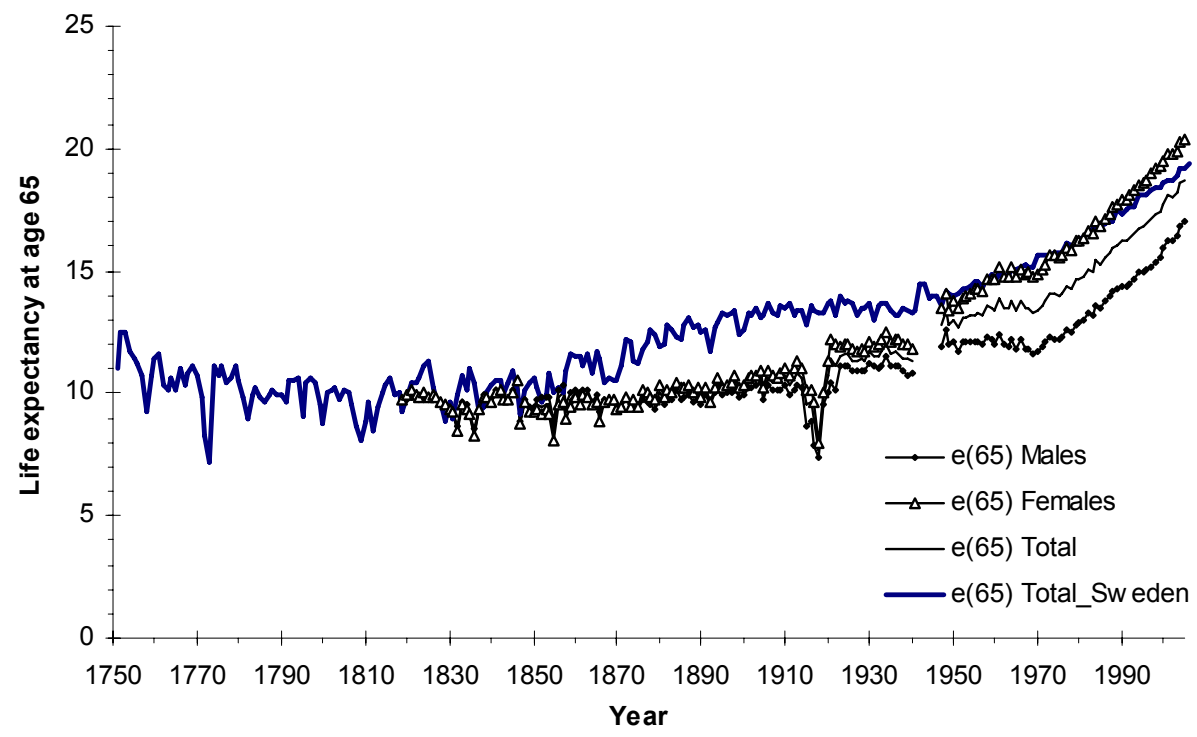

Notes: Estimates for the period of World War I are based on data on civilian deaths only. Data for Sweden (both sexes combined) shown for comparison. 
for contemporary researchers (Tafeln 1871) and at the time was attributed to an unusually favourable health situation expressed in a low number and lesser severity of epidemics.

\section{Conclusion}

The interpolating/correcting method used in the paper enabled us to reconstruct continuous time series of Austrian life tables and of population age-sex composition in 1870-1914 and in 1924-1940. The approach we propose may also be used in other studies on historical demography, wherever reconstructed dynamics are to be consistent with data for certain reference points and also with data on the dynamics of (albeit indirectly) related indicators. However, we could not fully reconstruct population and mortality dynamics during the wars. This task may be addressed again in the future, after the necessary data on war losses and on population movements during and after wars have been collected. Another way of improving the estimates would be to recalculate all life tables directly from population and deaths estimates. In doing so, our estimates might be helpful as they may provide (combined with census data on population) the necessary correction factors for estimating deaths for Austria from data on the Austrian Alpenländer.

Our reconstructions may also be used in studying the timing of other aspects of demographic transition in Austria, e.g., of fertility and of reproduction rates.

\section{References}

Bundeskanzleramt 1975. Bericht über die Situation der Frau in Österreich. Frauenbericht 1975. Heft 4. Die persönliche Situation der Frau. Die Freizeit der Frau. Wien: Österreichische Staatsdruckerei.

Bundeskanzleramt 1979. Bericht über die Situation der Familie in Österreich. Frauenbericht 1979. Heft 1. Struktur und Bedeutungswandel der Familie. Familie und Freizeit. Wien: Österreichische Staatsdruckerei.

Chiang, C.L. 1984. The Life Table and its Applications. Malabar, Florida: R.E. Krieger.

Ediev, D.M. 2001. "Reconstruction of the US Immigration History: Demographic Potential Approach." Investigated in Russia (Demographic section) 140e: 1619-1635. http://zhurnal.ape.relarn.ru/articles/2001/140e.pdf

Ediev, D.M. 2003. Demograficheskie poteri deportirovannyh narodov SSSR [Demographic losses of deported Soviet peoples]. Stavropol: AGRUS, Stavropolservisshkola. $336 \mathrm{pp}$.

Findl, P. 1979. "Mortalität und Lebenserwartung in den österreichischen Alpenländern im Zeitalter der Hochindustrialisierung (1868 bis 1912) ". In: Geschichte und Ergebnisse der zentralen amtlichen Statistik in Österreich 1829-1979. Wien, Österreichisches Statistisches Zentralamt, pp. 425-452. 
Gisser, R. 1979. "Daten zur Bevölkerungsentwicklung der österreichischen Alpenländer 1819 bis 1913. " In: Geschichte und Ergebnisse der zentralen amtlichen Statistik in Österreich 1829-1979. Wien, Österreichisches Statistisches Zentralamt, pp. 403-424.

HLD 2005. The Human Life-Table Database. Max Planck Institute for Demographic Research (Rostock, Germany), Department of Demography at the University of California (Berkeley, USA), and Institut national d'études démographiques (Paris, France). Accessed in Oct.-Nov. 2005. http://www.lifetable.de

HMD 2007. The Human Mortality Database by the Department of Demography at the University of California (Berkeley, USA) and Max Planck Institute for Demographic Research (Rostock, Germany). Accessed in 2007. http://www.mortality.org.

Landstätter, J. 1979. "Die Veränderung der Alterstruktur in Österreich seit 1869." In: Geschichte und Ergebnisse der zentralen amtlichen Statistik in Österreich 1829-1979. Wien, Österreichisches Statistisches Zentralamt, pp. 453-470.

Lee R. 1974. "Estimating series of vital rates and age structures from baptisms and burials: A new technique." Population Studies 28(3): 495-512.

Österreichisches Statistisches Zentralamt 1960. Entwicklung der Sterblichkeit in der Republik Österreich. Beiträge zur österreichischen Statistik, herausgegeben vom Österreichischen Statistischen Zentralamt, 47. Heft, Wien.

Österreichisches Statistisches Zentralamt 1967. Österreichische Sterbetafeln. Beiträge zur österreichischen Statistik, herausgegeben vom Österreichischen Statistischen Zentralamt, 144. Heft, Wien.

Pawlowsky, V. 2001. Mutter ledig - Vater Staat. Das Gebär- und Findelhaus in Wien 1784-1910. Innsbruck-Wien-München-Bozen: STUDIENVerlag.

Srb, V. 2004. 1000 let obyvatelstva Českých Zemí. Nakladatelství Karolinum, Univerzita Karlova (Charles University in Prague), Praha.

Statistik Austria, 2005. Demographisches Jahrbuch 2004. Wien: Statistik Austria.

Statistik des Bundesstaates Österreich 1935. Heft 1. Wien.

Tafeln 1871. "Tafeln", Neue Folge, V. Band. Wien.

Wrigley E.A. and R. Schofield. 1982. The Population History of England, 1541-1871. Edward Arnold and Harvard University Press.

Zeitschrift des Königlich Preussischen Statistischen Bureaus 1881. Zeitschrift des Königlich Preussischen Statistischen Bureaus, 21: 113ff. 